\title{
MINDSET ON USE OF OPEN ACCESS JOURNALS: A STUDY
}

\section{S. RAVI}

Dean, School of Communication, Professor and Head, Department of Library and Information Science,

Central University of Tamil Nadu, Thiruvarur, Tamil Nadu, India

\section{ABSTRACT}

The success of the use of Internet services and online services primarily depends on the prevailing mindset of the user. The same trend prevails in the case of online journals. In this study the mindset on the use of online journals among engineering professionals working in eight districts of Tamil Nadu was analyzed.

The study was carried out with the objective to identify the Awareness; source of awareness, place of access, usability, sufficiency, quality and satisfaction over the speed of access of open access journals The questionnaires were distributed to the Library and Information Science professionals of 76 engineering institutions. Nearly 210 questionnaires were distributed. Out of 210 distributed 157 responded and the response rate works out to $74.76 \%$.

Nearly $78.3 \%$ of the respondents have accessed the open access journals. Similarly, $60.4 \%$ of respondents have cited open access journals in their publications and 36.3\% of them published articles in open access journals. Out of 157 respondents, 87 (55.4\%) indicated that "through library" as their sources of awareness. It is followed by "Peers and Colleagues" $(38,24.2 \%)$ and "through guide" $(32,20.4 \%) .86(54.8 \%)$ respondents indicated that they access in all three locations such as home, office, and library whereas "Library" (39, 24.8\%) and "Home/Office" (32, 20.4\%). Nearly 80\% of respondents indicated the usability of open access journals as easy. Nearly $90 \%$ of respondents indicated little to highly satisfied with the sufficiency of open access journals. Nearly $75 \%$ of respondents indicated somewhat quality to very high quality of open access journals. Nearly $85 \%$ of respondents indicated somewhat fast to very fast towards the speed of access to open access journals.

In all, it seems that their existing mindset in use of open access journals among library professionals in Southern districts of Tamil Nadu.

KEYWORDS: Open Access Journal, Mindset On Use, Quality and Usability, Sufficiency of Open Access Journal \& Speed of Access

Received: Oct 31, 2018; Accepted: Nov 21, 2018; Published: Dec 07, 2018; Paper Id.: IJCMSDEC20186

\section{INTRODUCTION}

Today every one of us communicates and share the information with each other through the internet. This has deeply impacted scientific research and academic publishing also which facilitate the research publications were disseminated through many venues, including social media sites, blogs, Twitter, and Open Access (OA) scholarly journals that are freely available to anyone with Internet access.

Service to the public, both corporate and service industries primarily depends on the mindset, especially in their use. The same trend prevails in the case of internet services, online services and products. The trend on the use of online journals has been analyzed in this paper. 


\section{OPEN ACCESS JOURNALS}

Open Access Journals are scholarly journals. These journals are available online to users without financial, legal, or technical barriers other than those inseparable from gaining access to the Internet itself (Suber, 2006). The open access journals enhance the visibility. Open Access articles are downloaded and cited more frequently than articles from nonOAJs (Pandita, 2013 \& Kousha, 2009), and they reach broader audiences. Importantly, OAJs serve developing countries and small or specialized research institutions and corporations to have access to all Open Access articles (Ezema, 2011; Nwagwu, 2013).

Since its inception, usage of OAJs has become popular in universities and research institutes across the world where the number of articles published in OAJs increased from 40,000 in 2004 to 260,000 in 2014 (Ware \& Mobe, 2015). However, the global trend indicates unevenness in access to and usage of OAJs. Developed countries are leading in the exploitation of OAJs compared to underdeveloped countries, despite its existence of more than a decade. Most African countries exhibit a slow gain in the usage of OAJs which hinders the circulation of African publications (Nwagwu, 2013: Pandita, 2013). The open access journals are of two types such as Gold Open Access and Green Open Access

Some journals contain only open access articles whereas others, known as hybrid journals, may offer a mix of open and subscription content. In both cases, there are costs associated with publishing which need to be met. These costs, usually paid through article processing charges, may be paid by authors or subsidized by a third party such as a funding council. The article is made available immediately. This route is known as gold open access.

Green open access involves publishing in a traditional subscription journal as usual, but articles are also 'selfarchived' in a repository (institutional or external subject-based repository) and usually made available after an embargo period set by the publisher. No charges are paid. Today there exist 12000 open access journals (35 lakhs articles) covering all areas of science, technology, medicine, social science and humanities from 128 countries.

\section{REVIEW OF LITERATURE}

Many studies have been carried out on awareness and use of open access journals. Bartle and Walton, (1996) argue that most researchers are still reluctant to the use of Open Access Journals; one of the major reasons for this is that they are not aware of what is available to them and what the services are capable of doing. In a similar fashion, the results of the user survey, at the University of Hong Kong library (Woo, 2005; cited by Korobili, Tilikidou \& Delistarou 2005) shows that 68.8 percent of the respondents prefer to use open access journals compared to 31.2 percent who prefer to use printed journals. In Nigeria, studies such as those of Ureighe, Oroke, and Ekruyota (2006) found that access to and use open access resources is still low, the factors that may be accountable for the low use may be awareness and attitude of researchers.

Okoye, \& Ejikeme, (2010) indicated that with open access, articles can be accessed online free of charge. He identified inadequate skills to navigate the internet, unstable power supply, unavailability of internet facilities, the permanence of open access movement due to unstable financial support, lack of knowledge of the existence of open access journals on the internet as constraints to the use of open access journals by researchers.

Studies by Dulle, Minish-Majanja \& Cloete, 2010; Lwoga \& Questier (2014; Twaakyondo, 2013) identified low attitude and lack of trust in OAJs detriment OAJs behavior. Increased visibility, citation advantage, and high journal 
impacts are some of the benefits of publishing in Open Access (Kenneway, 2011; Suber, 2008; 2012; 2013). These are highly regarded in academic circles. Majority of authors that have published in high impact journals have not been enjoying the much-expected visibility and citations advantage as a result of licensing fees and other restrictions placed on subscription and access.

\section{OBJECTIVES OF THE STUDY}

The major objectives of the study were

- To identify the Awareness in open access journals.

- To know the Sources of awareness about open access journals

- To find out the Place of access to these open access journals.

- To identify the level of Usability of these open access journals

- To know the Sufficiency of the open access journals

- To know the Quality of open access journals

- To identify the satisfaction over Speed of Access of open access journals.

\section{DATA COLLECTION}

The questionnaires were distributed to the Library and Information Science professionals of 76 engineering institutions. Nearly 210 questionnaires were distributed. Out of 210 distributed 157 responded. The response rate works out to $74.76 \%$.

\section{DEMOGRAPHIC DETAILS}

The demographic details of the respondents were shown in Table 1.

Table 1: Demographic Details

\begin{tabular}{|c|c|c|c|}
\hline S. No & Description & \multicolumn{2}{|c|}{ Respondents } \\
\hline \multicolumn{4}{|c|}{ District } \\
\hline 1 & Ariyalur & 10 & $6.4 \%$ \\
\hline 2 & Cuddalore & 16 & $10.2 \%$ \\
\hline 3 & Nagapattinan & 6 & $0.2 \%$ \\
\hline 4 & Perambalur & 16 & $0.2 \%$ \\
\hline 5 & Thanjavour & 25 & $15.9 \%$ \\
\hline 6 & Thiruvannamalai & 24 & $15.3 \%$ \\
\hline 7 & Thiruvarur & $\overline{6}$ & $3.8 \%$ \\
\hline 8 & Villupuram & 44 & $28.0 \%$ \\
\hline \multicolumn{4}{|c|}{ Gender } \\
\hline 1 & Male & 94 & $59.9 \%$ \\
\hline 2 & Female & 63 & $40.1 \%$ \\
\hline \multicolumn{4}{|c|}{ Designation } \\
\hline 1 & Librarian & 121 & $77.1 \%$ \\
\hline 2 & Asst. Librarian & 18 & $11.45 \%$ \\
\hline 3 & Others & 18 & $11.45 \%$ \\
\hline \multicolumn{4}{|c|}{ Overall } \\
\hline & Total & 157 & $100.0 \%$ \\
\hline
\end{tabular}




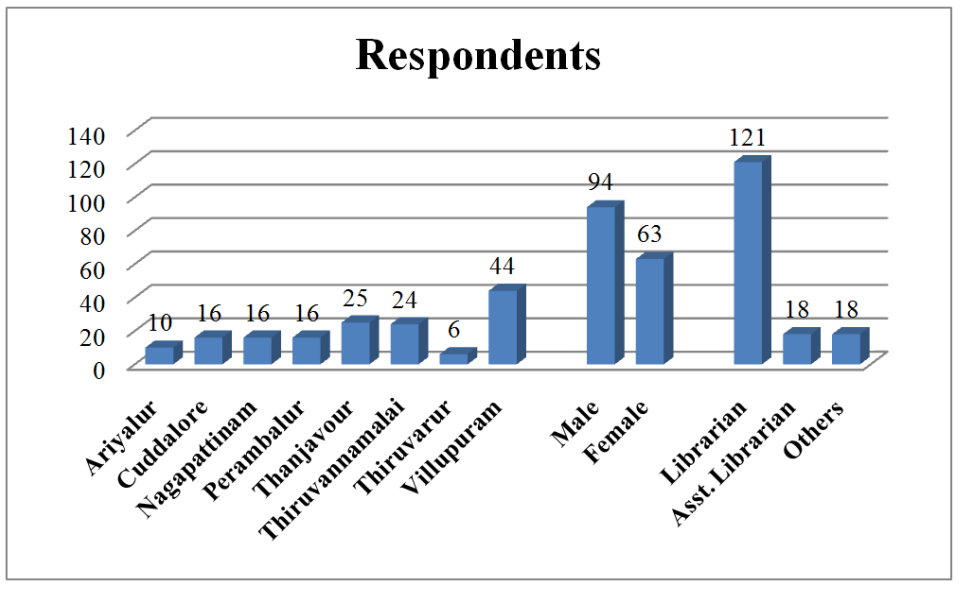

Figure 1: Demographic Details

\section{DATA ANALYSIS}

The use of open access journals was analyzed based on

- Awareness

- $\quad$ Sources of awareness

- $\quad$ Place of access

- Usability

- Sufficiency

- Quality

- $\quad$ Speed of Access

\section{Awareness on Open Access Journals}

Awareness of open access journal has been ascertained based on access, cite and publish. The same has been shown in Table 2.

Table 2: Awareness of Open Access

\begin{tabular}{|l|l|l|l|}
\hline S. No & Description & No. of Persons & Percent \\
\hline 1 & Access & 123 & 78.3 \\
\hline 2 & Cited & 109 & 60.4 \\
\hline 3 & Published & 57 & 36.3 \\
\hline
\end{tabular}

Nearly $78.3 \%$ of the respondent have accessed the open access journals. Similarly, $60.4 \%$ of respondents have cited open access journals in their publications. It is quite interesting to note that $36.3 \%$ of used published articles in open access journals.

The study has further been extended to the district, gender, and designation. The same has been shown in Table 3 . 
Table 3: Awareness of Open Access Vs District, Gender, Designation

\begin{tabular}{|l|l|c|c|c|c|c|c|c|c|}
\hline S. No & Description & Access & $\%$ & Cited & $\%$ & Published & $\%$ & Total & $\%$ \\
\hline \multicolumn{8}{|c|}{ District } \\
\hline 1 & Ariyalur & 8 & $80.0 \%$ & 7 & $70.0 \%$ & 3 & $30.0 \%$ & 10 & $100.0 \%$ \\
\hline 2 & Cuddalore & 12 & $75.0 \%$ & 11 & $68.8 \%$ & 6 & $37.5 \%$ & 16 & $100.0 \%$ \\
\hline 3 & Nagapattinam & 13 & $81.3 \%$ & 11 & $68.8 \%$ & 5 & $31.3 \%$ & 16 & $100.0 \%$ \\
\hline 4 & Perambalur & 13 & $81.3 \%$ & 12 & $75.0 \%$ & 6 & $37.5 \%$ & 16 & $100.0 \%$ \\
\hline 5 & Thanjavur & 18 & $72.0 \%$ & 16 & $64.0 \%$ & 9 & $36.0 \%$ & 25 & $100.0 \%$ \\
\hline 6 & Tiruvannamalai & 20 & $83.3 \%$ & 17 & $70.8 \%$ & 8 & $33.3 \%$ & 24 & $100.0 \%$ \\
\hline 7 & Tiruvarur & 3 & $50.0 \%$ & 3 & $50.0 \%$ & 4 & $66.7 \%$ & 6 & $100.0 \%$ \\
\hline 8 & Villupuram & 36 & $81.8 \%$ & 32 & $72.7 \%$ & 16 & $36.4 \%$ & 44 & $100.0 \%$ \\
\hline \multicolumn{8}{|c|}{ Gender } \\
\hline 1 & Male & 71 & $75.5 \%$ & 62 & $66.0 \%$ & 33 & $35.1 \%$ & 94 & $100.0 \%$ \\
\hline 2 & Female & 52 & $82.5 \%$ & 47 & $74.6 \%$ & 24 & $38.1 \%$ & 63 & $100.0 \%$ \\
\hline \multicolumn{8}{|c|}{ Designation } \\
\hline 1 & Librarian & 93 & $76.9 \%$ & 83 & $68.6 \%$ & 44 & $36.4 \%$ & 121 & $100.0 \%$ \\
\hline 2 & Asst. Librarian & 16 & $88.9 \%$ & 13 & $72.2 \%$ & 7 & $38.9 \%$ & 18 & $100.0 \%$ \\
\hline 3 & Others & 14 & $77.8 \%$ & 13 & $72.2 \%$ & 6 & $33.3 \%$ & 18 & $100.0 \%$ \\
\hline \multicolumn{8}{|c|}{ Overall } \\
\hline
\end{tabular}

In the case of access, the percentage of access to open access journal ranges between 50 to $81.8 \%$. Ariyalur (80.0\%), Nagapattinam (81.3\%), Perambalur (81.3\%), Tiruvannamalai (83.3\%) and Villupuram (81.8\%) respondents access more open access journals. Tiruvarur (50\%) respondents have the least access in open access journal. Female $(82.5 \%)$ access more open access journal than male (75.5\%). Asst. Librarian $(88.9 \%)$ access more open access journals than other library professionals $(77.8 \%)$ and Librarians $(76.9 \%)$

In relation to the citation, the percentage of citation of open access journal ranges between 50 to $75 \%$. Ariyalur (70.0\%), Perambalur (75.0\%), Tiruvannamalai (70.8\%) and Villupuram (72.7\%) respondents cite more open access journals. Tiruvarur (50\%) respondents have least cited in open access journal. Female (74.6\%) cite more open access journal than male $(66.0 \%)$. Both Asst. Librarian (72.2\%) and other library professionals (72.2\%) cite more open access journals than the Librarians $(68.6 \%)$.

The publication of papers in open access journal ranges between 30 to $66.7 \%$. Tiruvarur has a maximum of $66.7 \%$ respondents publish a paper in Open access journals. It is followed by Cuddalore and Perambalur (37.5\%); Villupuram (36.4\%); Thanjavur (36.0\%) and Tiruvannamalai (33.3\%). Ariyalur (30\%) respondents have least published in open access journal. Female (38.1\%) publish their papers more open access journal than male (35.1\%). Asst. Librarian (38.9\%) publish more papers in open access journals than Librarians (36.4\%) and other library professionals (33.3\%).

\section{Sources of Awareness of Open Access Journals}

The source of awareness by the respondents was analyzed based on "Through Library"; "Through Guide" and "Peers and Colleagues". The responses were shown in Table 4

Table 4: Sources of Awareness of Open Access Journals

\begin{tabular}{|c|c|c|c|}
\hline S. No. & Description & No. of Persons & Percent \\
\hline 1 & Through Library & 87 & $55.4 \%$ \\
\hline 2 & Through Guide & 32 & $20.4 \%$ \\
\hline 3 & Peers and Colleagues & 38 & $24.2 \%$ \\
\hline & Total & $\mathbf{1 5 7}$ & $\mathbf{1 0 0 . 0 0 \%}$ \\
\hline
\end{tabular}


Out of 157 respondents, $87(55.4 \%)$ indicated that "through library" as their sources of awareness. It is followed by "Peers and Colleagues" (38, 24.2\%) and "through guide" $(32,20.4 \%)$.

The study has further been extended to the district, gender, and designation. The same has been shown in Table 5 .

Table 5: Source of Awareness of Open Access Journals vs District, Gender, Designation

\begin{tabular}{|c|c|c|c|c|c|c|c|c|c|}
\hline S. No & Description & $\begin{array}{l}\text { Through } \\
\text { Library }\end{array}$ & $\%$ & $\begin{array}{c}\text { Through } \\
\text { Guide }\end{array}$ & $\%$ & $\begin{array}{l}\text { Peers and } \\
\text { Colleagues }\end{array}$ & $\%$ & Total & $\%$ \\
\hline \multicolumn{10}{|c|}{ District } \\
\hline 1 & Ariyalur & 8 & $80.0 \%$ & 2 & $20.0 \%$ & 0 & $.0 \%$ & 10 & $100.0 \%$ \\
\hline 2 & Cuddalore & 7 & $43.8 \%$ & 4 & $25.0 \%$ & 5 & $31.3 \%$ & 16 & $100.0 \%$ \\
\hline 3 & Nagapattinam & 7 & $43.8 \%$ & 4 & $25.0 \%$ & 5 & $31.3 \%$ & 16 & $100.0 \%$ \\
\hline 4 & Perambalur & 9 & $56.3 \%$ & 2 & $12.5 \%$ & 5 & $31.3 \%$ & 16 & $100.0 \%$ \\
\hline 5 & Thanjavur & 16 & $64.0 \%$ & 6 & $24.0 \%$ & 3 & $12.0 \%$ & 25 & $100.0 \%$ \\
\hline 6 & Tiruvannamalai & 15 & $62.5 \%$ & 4 & $16.7 \%$ & 5 & $20.8 \%$ & 24 & $100.0 \%$ \\
\hline 7 & Tiruvarur & 3 & $50.0 \%$ & 1 & $16.7 \%$ & 2 & $33.3 \%$ & 6 & $100.0 \%$ \\
\hline 8 & Villupuram & 22 & $50.0 \%$ & 9 & $20.5 \%$ & 13 & $29.5 \%$ & 44 & $100.0 \%$ \\
\hline \multicolumn{10}{|c|}{ Gender } \\
\hline 1 & Male & 53 & $56.4 \%$ & 18 & $19.1 \%$ & 23 & $24.5 \%$ & 94 & $100.0 \%$ \\
\hline 2 & Female & 34 & $54.0 \%$ & 14 & $22.2 \%$ & 15 & $23.8 \%$ & 63 & $100.0 \%$ \\
\hline \multicolumn{10}{|c|}{ Designation } \\
\hline 1 & Librarian & 66 & $54.5 \%$ & 25 & $20.7 \%$ & 30 & $24.8 \%$ & 121 & $100.0 \%$ \\
\hline 2 & Asst. Librarian & 12 & $66.7 \%$ & 3 & $16.7 \%$ & 3 & $16.7 \%$ & 18 & $100.0 \%$ \\
\hline 3 & Others & 9 & $50.0 \%$ & 4 & $22.2 \%$ & 5 & $27.8 \%$ & 18 & $100.0 \%$ \\
\hline \multicolumn{10}{|c|}{ Overall } \\
\hline & Total & 87 & $55.4 \%$ & 32 & $20.4 \%$ & 38 & $24.2 \%$ & 157 & $100.0 \%$ \\
\hline
\end{tabular}

In the case of the source of awareness on open access journals among districts, nearly $55.4 \%$ indicated through the library. The percentage ranges from 50 to $80 \%$. Ariyalur (80.0\%), Thanjavur (64\%) and Tiruvannamalai $(62.5 \%)$ were indicated through the library. Tiruvarur and Villupuram (50\%) respondents have indicated least. Male (56.4\%) indicated the source of information as a library than female (54.0\%). Asst. Librarian (66.7\%) indicated source through the library. It is followed by Librarians $(54.5 \%)$ and other library professionals $(50.0 \%)$.

In the case of the source through the guide, the percentage ranges between 12.5 to $25 \%$. Cuddalore and Nagapattinam (50.0\%), Thanjavur (24.0\%) and Villupuram (20.5\%) respondents indicated through the guide. Perambalur (12.5\%) respondents have least opted for through guide. 22.2\% of female opted for through guide than male (19.1\%). $22.2 \%$ of other library professionals indicated through the guide. It is followed by librarians (20.7\%) and Asst. Librarians $(22.2 \%)$

24.2\% of respondents indicated Peers and colleagues as a source of awareness for open access journals. In the case districts, the percentage ranges between 0 to 33.3\%. A maximum of 33.3\% respondents of Tiruvarur indicated Peers and colleagues as source of inspiration for open access journals. Nearly 31.3\% of respondents of Cuddalore, Nagapattinam, and Perambalur indicated peers and colleagues were the inspiration on open access journals. Thanjavur (12.4\%) respondents have least opted for peer and colleagues. $24.5 \%$ of male opted for peer and colleagues than male (23.8\%). $27.8 \%$ of other library professionals indicated peer and colleagues. It is followed by librarians (24.8\%) and Asst. Librarians $(16.7 \%)$. 


\section{Place of Access of Open Access Journals}

The place of access to open access journals by the respondents was analyzed based on "Home/Office"; "Library" and "All three locations". The responses were shown in Table 6

Table 6: Place of Access of Open Access Journals

\begin{tabular}{|c|c|c|c|}
\hline S. No & Description & No. of Persons & Percent \\
\hline 1 & Home/Office & 32 & $20.4 \%$ \\
\hline 2 & Library & 39 & $24.8 \%$ \\
\hline 3 & All three locations & 86 & $54.8 \%$ \\
\hline & Total & 157 & $100.00 \%$ \\
\hline
\end{tabular}

$86(54.8 \%)$ respondents indicated that they access in all three locations. It is followed by "Library" $(39,24.8 \%)$ and "Home/Office" (32, 20.4\%).

The study has further been extended to the district, gender, and designation. The same has been shown in Table 7.

Table 7: Place of Access of Open Access Journals Vs District, Gender, Designation

\begin{tabular}{|c|c|c|c|c|c|c|c|c|c|}
\hline \multirow{2}{*}{ S. No } & \multirow{2}{*}{ Description } & \multicolumn{2}{|c|}{ Home/Office } & \multicolumn{2}{|c|}{ Library } & \multicolumn{2}{|c|}{ All Three Locations } & \multirow{2}{*}{ Total } & \multirow{2}{*}{$\%$} \\
\hline & & No. of Users & $\%$ & No. of Users & $\%$ & No. of Users & $\%$ & & \\
\hline \multicolumn{10}{|c|}{ District } \\
\hline 1 & Ariyalur & 2 & $20.0 \%$ & 4 & $40.0 \%$ & 4 & $40.0 \%$ & 10 & $100.0 \%$ \\
\hline 2 & Cuddalore & 4 & $25.0 \%$ & 3 & $18.8 \%$ & 9 & $56.3 \%$ & 16 & $100.0 \%$ \\
\hline 3 & Nagapattinam & 2 & $12.5 \%$ & 3 & $18.8 \%$ & 11 & $68.8 \%$ & 16 & $100.0 \%$ \\
\hline 4 & Perambalur & 4 & $25.0 \%$ & 4 & $25.0 \%$ & 8 & $50.0 \%$ & 16 & $100.0 \%$ \\
\hline 5 & Thanjavur & 6 & $24.0 \%$ & 7 & $28.0 \%$ & 12 & $48.0 \%$ & 25 & $100.0 \%$ \\
\hline 6 & Tiruvannamalai & 4 & $16.7 \%$ & 7 & $29.2 \%$ & 13 & $54.2 \%$ & 24 & $100.0 \%$ \\
\hline 7 & Tiruvarur & 2 & $33.3 \%$ & 0 & $.0 \%$ & 4 & $66.7 \%$ & 6 & $100.0 \%$ \\
\hline 8 & Villupuram & 8 & $18.2 \%$ & 11 & $25.0 \%$ & 25 & $56.8 \%$ & 44 & $100.0 \%$ \\
\hline \multicolumn{10}{|c|}{ Gender } \\
\hline 1 & Male & 22 & $23.4 \%$ & 21 & $22.3 \%$ & 51 & $54.3 \%$ & 94 & $100.0 \%$ \\
\hline 2 & Female & 10 & $15.9 \%$ & 18 & $28.6 \%$ & 35 & $55.6 \%$ & 63 & $100.0 \%$ \\
\hline \multicolumn{10}{|c|}{ Designation } \\
\hline 1 & Librarian & 25 & $20.7 \%$ & 31 & $25.6 \%$ & 65 & $53.7 \%$ & 121 & $100.0 \%$ \\
\hline 2 & Asst. Librarian & 3 & $16.7 \%$ & 5 & $27.8 \%$ & 10 & $55.6 \%$ & 18 & $100.0 \%$ \\
\hline 3 & Others & 4 & $22.2 \%$ & 3 & $16.7 \%$ & 11 & $61.1 \%$ & 18 & $100.0 \%$ \\
\hline \multicolumn{10}{|c|}{ Overall } \\
\hline & Total & 32 & $20.4 \%$ & 39 & $24.8 \%$ & 86 & $54.8 \%$ & 157 & $100.0 \%$ \\
\hline
\end{tabular}

In the case of home/office as the place of access to open access journal, the percentage ranges between 12.5 to 33.3\%. Tiruvarur (33.3\%), Cuddalore and Nagapattinam (25.0\%), Thanjavur (24.0\%) and Ariyalur (20.0\%) respondents access more from home/office. Nagapattinam (12.5\%) respondents have the least access from home/office. Male (23.4\%) access more open access journal from home/office than female (15.9\%). Other library professionals (22.2\%) access more open access journals in home/office than Librarians (20.7\%) and Asst. Librarians (16.7\%).

Nearly 0 to $40 \%$ of respondents in district indicated Library as a place of access of open access journal. Ariyalur (40.0\%), Perambalur (25.0\%), Thanjavur (28.0\%), Tiruvannamalai $(29.2 \%)$ and Villupuram (25.0\%) respondents indicated library as a place of access for open access journals. None of the respondents of Tiruvarur has used the library as place of access to open access journal. Female (28.6\%) use library more for accessing open access journal than male (22.3\%). Asst. Librarian $(27.8 \%)$ use the library for accessing open access journal than librarians $(25.6 \%)$ and other library professionals $(16.7 \%)$. 
Nearly $40 \%$ to $68.8 \%$ of respondents use all the three locations for accessing open access journals. Nagapattinam has a maximum of $68.8 \%$ respondents. It is followed by Tiruvarur (66.7\%), Villupuram (56.8\%); Cuddalore (56.3\%), Tiruvannamalai (54.2\%). and Perambalur (50\%). Thanjavur (48\%) and Ariyalur (40\%) respondents have least used all three locations for accessing the open access journal. Female (55.6\%) use all three locations for accessing more open access journal than male (54.3\%). Other library professionals $(61.1 \%)$ use all three locations for accessing the open access journals than Asst. Librarian (55.6\%) and Librarians (53.7\%).

\section{Usability of OAJ Journals}

The respondent's opinion on usability of open access journals were obtained in a five-point scale such as very difficult, difficult, somewhat easy, easy and very easy and the same has been analyzed. The responses were shown in Table 8.

Table 8: Usability of Open Access Journals

\begin{tabular}{|c|c|c|c|}
\hline S. No & Description & Frequency & Percent \\
\hline 1 & Very difficult & 8 & 5.1 \\
\hline 2 & Difficult & 24 & 15.3 \\
\hline 3 & Somewhat easy & 25 & 15.9 \\
\hline 4 & Easy & 47 & 29.9 \\
\hline \multirow{2}{*}{ 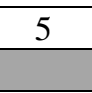 } & Very Easy & 53 & 33.8 \\
\hline & Total & 157 & 100.0 \\
\hline
\end{tabular}

Nearly $80 \%$ of respondents indicated the usability of open access journals as easy. $33.8 \%$ of respondents indicated very easy. It is followed by easy (29.9\%) and somewhat easy (15.9\%). Only $20.4 \%$ indicated usability as difficult (15.3\%) and very difficult $(5.1 \%)$.

The study has further been extended to the district, gender, and designation. The same has been shown in Table 9.

Table 9: Usability of Open Access Journals Vs District, Gender, Designation

\begin{tabular}{|c|c|c|c|c|c|c|c|c|c|c|c|c|c|}
\hline S. No & Description & & $\begin{array}{l}\text { Very } \\
\text { ifficult }\end{array}$ & \multicolumn{2}{|c|}{ Difficult } & \multicolumn{2}{|c|}{$\begin{array}{c}\text { Somewhat } \\
\text { Easy }\end{array}$} & \multicolumn{2}{|c|}{ Easy } & \multicolumn{2}{|c|}{ Very Easy } & \multicolumn{2}{|c|}{ Total } \\
\hline \multicolumn{14}{|c|}{ District } \\
\hline 1 & Ariyalur & 1 & $10.0 \%$ & 2 & $20.0 \%$ & 1 & $10.0 \%$ & 3 & $30.0 \%$ & 3 & $30.0 \%$ & 10 & $100.0 \%$ \\
\hline 2 & Cuddalore & 1 & $6.3 \%$ & 2 & $12.5 \%$ & 3 & $18.8 \%$ & 5 & $31.3 \%$ & 5 & $31.3 \%$ & 16 & $100.0 \%$ \\
\hline 3 & Nagapattinam & 0 & $.0 \%$ & 2 & $12.5 \%$ & 2 & $12.5 \%$ & 5 & $31.3 \%$ & 7 & $43.8 \%$ & 16 & $100.0 \%$ \\
\hline 4 & Perambalur & 1 & $6.3 \%$ & 2 & $12.5 \%$ & 3 & $18.8 \%$ & 5 & $31.3 \%$ & 5 & $31.3 \%$ & 16 & $100.0 \%$ \\
\hline 5 & Thanjavur & 2 & $8.0 \%$ & 5 & $20.0 \%$ & 4 & $16.0 \%$ & 6 & $24.0 \%$ & 8 & $32.0 \%$ & 25 & $100.0 \%$ \\
\hline 6 & Tiruvannamalai & 1 & $4.2 \%$ & 4 & $16.7 \%$ & 3 & $12.5 \%$ & 7 & $29.2 \%$ & 9 & $37.5 \%$ & 24 & $100.0 \%$ \\
\hline 7 & Tiruvarur & 0 & $.0 \%$ & 1 & $16.7 \%$ & 2 & $33.3 \%$ & 2 & $33.3 \%$ & 1 & $16.7 \%$ & 6 & $100.0 \%$ \\
\hline 8 & Villupuram & 2 & $4.5 \%$ & 6 & $13.6 \%$ & 7 & $15.9 \%$ & 14 & $31.8 \%$ & 15 & $34.1 \%$ & 44 & $100.0 \%$ \\
\hline \multicolumn{14}{|c|}{ Gender } \\
\hline 1 & Male & 5 & $5.3 \%$ & 14 & $14.9 \%$ & 15 & $16.0 \%$ & 26 & $27.7 \%$ & 34 & $36.2 \%$ & 94 & $100.0 \%$ \\
\hline 2 & Female & 3 & $4.8 \%$ & 10 & $15.9 \%$ & 10 & $15.9 \%$ & 21 & $33.3 \%$ & 19 & $30.2 \%$ & 63 & $100.0 \%$ \\
\hline \multicolumn{14}{|c|}{ Designation } \\
\hline 1 & Librarian & 6 & $5.0 \%$ & 17 & $14.0 \%$ & 20 & $16.5 \%$ & 37 & $30.6 \%$ & 41 & $33.9 \%$ & 121 & $100.0 \%$ \\
\hline 2 & Asst. Librarian & 1 & $5.6 \%$ & 4 & $22.2 \%$ & 3 & $16.7 \%$ & 5 & $27.8 \%$ & 5 & $27.8 \%$ & 18 & $100.0 \%$ \\
\hline 3 & Others & 1 & $5.6 \%$ & 3 & $16.7 \%$ & 2 & $11.1 \%$ & 5 & $27.8 \%$ & 7 & $38.9 \%$ & 18 & $100.0 \%$ \\
\hline \multicolumn{14}{|c|}{ Overall } \\
\hline & Total & 8 & $5.1 \%$ & 24 & $15.3 \%$ & 25 & $15.9 \%$ & 47 & $29.9 \%$ & 53 & $33.8 \%$ & 157 & $100.0 \%$ \\
\hline
\end{tabular}

$30 \%$ to $44 \%$ of the respondents indicated the usability of open access journals as very easy. Among them, $43.8 \%$ of Nagapattinam respondents indicated very easy. It is followed by Tiruvannamalai (37.5\%), Villupuram (34.1\%) and 
Thanjavur (32\%). Similarly, 36.2\% of male indicated very easy than female (30.2\%). 38.9\% of other library professionals indicated very easy. It is followed by Librarian (33.9\%) and Asst. Librarians (27.8\%)

\section{Sufficient Journals}

The respondent's opinion on Sufficiency of open access journals were obtained in a five-point scale such as not at all, little, average, satisfied and highly satisfied and the same has been analyzed. The responses were shown in Table 10.

Table 10: Sufficiency of Open Access Journals

\begin{tabular}{|c|l|c|c|c|}
\hline S. No & Description & Frequency & Percent & Cumulative Percent \\
\hline 1 & Not at all & 16 & 10.2 & 10.2 \\
\hline 2 & Little & 23 & 14.6 & 24.8 \\
\hline 3 & Average & 32 & 20.4 & 45.2 \\
\hline 4 & Satisfied & 40 & 25.5 & 70.7 \\
\hline 5 & Highly Satisfied & 46 & 29.3 & 100.0 \\
\hline \multicolumn{2}{|c|}{ Total } & $\mathbf{1 5 7}$ & $\mathbf{1 0 0 . 0}$ & \\
\hline
\end{tabular}

Nearly $90 \%$ of respondents indicated little too highly satisfied with the sufficiency of open access journals. $29.3 \%$ of respondents highly satisfied with open access journals. It is followed by satisfied (25.5\%), average (20.4\%) and little $(24.8 \%)$. Only $10.2 \%$ indicated not at all sufficient.

The study has further been extended to the district, gender, and designation. The same has been shown in Table 11.

Table 11: Sufficiency of Open Access Journals Vs District, Gender, Designation

\begin{tabular}{|c|c|c|c|c|c|c|c|c|c|c|c|c|c|}
\hline S. No & Description & \multicolumn{2}{|c|}{ Not at All } & \multicolumn{2}{|c|}{ Little } & \multicolumn{2}{|c|}{ Average } & \multicolumn{2}{|c|}{ Satisfied } & \multicolumn{2}{|c|}{ Highly Satisfied } & \multicolumn{2}{|c|}{ Total } \\
\hline \multicolumn{14}{|c|}{ District } \\
\hline 1 & Ariyalur & 1 & $10.0 \%$ & 2 & $20.0 \%$ & 2 & $20.0 \%$ & 2 & $20.0 \%$ & 3 & $30.0 \%$ & 10 & $100.0 \%$ \\
\hline 2 & Cuddalore & 2 & $12.5 \%$ & 3 & $18.8 \%$ & 3 & $18.8 \%$ & 4 & $25.0 \%$ & 4 & $25.0 \%$ & 16 & $100.0 \%$ \\
\hline 3 & Nagapattinam & 2 & $12.5 \%$ & 1 & $6.3 \%$ & 3 & $18.8 \%$ & 4 & $25.0 \%$ & 6 & $37.5 \%$ & 16 & $100.0 \%$ \\
\hline 4 & Perambalur & 1 & $6.3 \%$ & 3 & $18.8 \%$ & 4 & $25.0 \%$ & 5 & $31.3 \%$ & 3 & $18.8 \%$ & 16 & $100.0 \%$ \\
\hline 5 & Thanjavur & 3 & $12.0 \%$ & 4 & $16.0 \%$ & 4 & $16.0 \%$ & 5 & $20.0 \%$ & 9 & $36.0 \%$ & 25 & $100.0 \%$ \\
\hline 6 & Tiruvannamalai & 2 & $8.3 \%$ & 3 & $12.5 \%$ & 5 & $20.8 \%$ & 6 & $25.0 \%$ & 8 & $33.3 \%$ & 24 & $100.0 \%$ \\
\hline 7 & Tiruvarur & 1 & $16.7 \%$ & 0 & $.0 \%$ & 2 & $33.3 \%$ & 2 & $33.3 \%$ & 1 & $16.7 \%$ & 6 & $100.0 \%$ \\
\hline 8 & Villupuram & 4 & $9.1 \%$ & 7 & $15.9 \%$ & 9 & $20.5 \%$ & 12 & $27.3 \%$ & 12 & $27.3 \%$ & 44 & $100.0 \%$ \\
\hline \multicolumn{14}{|c|}{ Gender } \\
\hline 1 & Male & 10 & $10.6 \%$ & 12 & $12.8 \%$ & 18 & $19.1 \%$ & 23 & $24.5 \%$ & 31 & $33.0 \%$ & 94 & $100.0 \%$ \\
\hline 2 & Female & 6 & $9.5 \%$ & 11 & $17.5 \%$ & 14 & $22.2 \%$ & 17 & $27.0 \%$ & 15 & $23.8 \%$ & 63 & $100.0 \%$ \\
\hline \multicolumn{14}{|c|}{ Designation } \\
\hline 1 & Librarian & 12 & $9.9 \%$ & 16 & $13.2 \%$ & 25 & $20.7 \%$ & 32 & $26.4 \%$ & 36 & $29.8 \%$ & 121 & $100.0 \%$ \\
\hline 2 & Asst. Librarian & 2 & $11.1 \%$ & 4 & $22.2 \%$ & 4 & $22.2 \%$ & 4 & $22.2 \%$ & 4 & $22.2 \%$ & 18 & $100.0 \%$ \\
\hline 3 & Others & 2 & $11.1 \%$ & 3 & $16.7 \%$ & 3 & $16.7 \%$ & 4 & $22.2 \%$ & 6 & $33.3 \%$ & 18 & $100.0 \%$ \\
\hline \multicolumn{14}{|c|}{ Overall } \\
\hline & Total & 16 & $10.2 \%$ & 23 & $14.6 \%$ & 32 & $20.4 \%$ & 40 & $25.5 \%$ & 46 & $29.3 \%$ & 157 & $100.0 \%$ \\
\hline
\end{tabular}

$16.7 \%$ to $36 \%$ of the respondents were highly satisfied with sufficient open access journals. Similarly $20 \%$ to $33.3 \%$ indicated satisfied and $16 \%$ to $33.3 \%$ as average. Not at all sufficient ranges between $6.3 \%$ and $16.7 \%$. Among them, $37.5 \%$ of Nagapattinam respondents indicated Highly satisfied. It is followed by Thanjavur (36\%), Tiruvannamalai (33.3\%) and Ariyalur (30\%). Similarly, 33.3\% of male indicated highly satisfied than female (23.8\%). 33.3\% of other library professionals indicated highly satisfied. It is followed by Librarian (29.8\%) and Asst. Librarians (22.2\%). 


\section{Quality of Open Access Journals}

The respondent's opinion on the quality of open access journals were obtained in a five-point scale such as Very poor quality, Poor quality, somewhat quality, high quality, and very high quality and the same has been analyzed. The responses were shown in Table 12.

Table 12: Quality of OAJ Articles

\begin{tabular}{|c|c|c|c|c|}
\hline S. No & Description & Frequency & Percent & Cumulative Percent \\
\hline 1 & Very Poor Quality & 24 & 15.3 & 15.3 \\
\hline 2 & Poor Quality & 15 & 9.6 & 24.8 \\
\hline 3 & Somewhat Quality & 40 & 25.5 & 50.3 \\
\hline 4 & High Quality & 47 & 29.9 & 80.3 \\
\hline 5 & Very High Quality & 31 & 19.7 & 100.0 \\
\hline & Total & 157 & 100.0 & \\
\hline
\end{tabular}

Nearly $75 \%$ of respondents indicated somewhat quality to very high quality of open access journals. $19.7 \%$ of respondents indicated very high quality to open access journals. It is followed by high quality (29.9\%) and somewhat quality $(25.5 \%)$. Only $24.8 \%$ indicated very poor quality to poor quality.

The study has further been extended to the district, gender, and designation. The same has been shown in Table 13.

Table 13: Quality of Open Access Journals Vs District, Gender, Designation

\begin{tabular}{|c|c|c|c|c|c|c|c|c|c|c|c|c|c|}
\hline $\begin{array}{l}\text { S. } \\
\text { No }\end{array}$ & Description & \multicolumn{2}{|c|}{$\begin{array}{c}\text { Very Poor } \\
\text { Quality }\end{array}$} & & $\begin{array}{l}\text { Poor } \\
\text { uality }\end{array}$ & \multicolumn{2}{|c|}{$\begin{array}{c}\text { Somewhat } \\
\text { High } \\
\text { Quality }\end{array}$} & \multicolumn{2}{|c|}{$\begin{array}{c}\text { High } \\
\text { Quality }\end{array}$} & \multicolumn{2}{|c|}{$\begin{array}{c}\text { Very High } \\
\text { Quality }\end{array}$} & \multicolumn{2}{|c|}{ Total } \\
\hline \multicolumn{14}{|c|}{ District } \\
\hline 1 & Ariyalur & 2 & $20.0 \%$ & 1 & $10.0 \%$ & 3 & $30.0 \%$ & 3 & $30.0 \%$ & 1 & $10.0 \%$ & 10 & $100.0 \%$ \\
\hline 2 & Cuddalore & 3 & $18.8 \%$ & 2 & $12.5 \%$ & 3 & $18.8 \%$ & 4 & $25.0 \%$ & 4 & $25.0 \%$ & 16 & $100.0 \%$ \\
\hline 3 & Nagapattinam & 2 & $12.5 \%$ & 1 & $6.3 \%$ & 4 & $25.0 \%$ & 5 & $31.3 \%$ & 4 & $25.0 \%$ & 16 & $100.0 \%$ \\
\hline 4 & Perambalur & 2 & $12.5 \%$ & 2 & $12.5 \%$ & 4 & $25.0 \%$ & 5 & $31.3 \%$ & 3 & $18.8 \%$ & 16 & $100.0 \%$ \\
\hline 5 & Thanjavur & 5 & $20.0 \%$ & 2 & $8.0 \%$ & 6 & $24.0 \%$ & 7 & $28.0 \%$ & 5 & $0.0 \%$ & 25 & $100.0 \%$ \\
\hline 6 & Tiruvannamalai & 3 & $12.5 \%$ & 2 & $8.3 \%$ & 7 & $29.2 \%$ & 8 & $33.3 \%$ & 4 & $16.7 \%$ & 24 & $100.0 \%$ \\
\hline 7 & Tiruvarur & 1 & $16.7 \%$ & 0 & $.0 \%$ & 2 & $33.3 \%$ & 2 & $33.3 \%$ & 1 & $16.7 \%$ & 6 & $100.0 \%$ \\
\hline 8 & Villupuram & 6 & $13.6 \%$ & 5 & $11.4 \%$ & 11 & $25.0 \%$ & 13 & $29.5 \%$ & 9 & $20.5 \%$ & 44 & $100.0 \%$ \\
\hline \multicolumn{14}{|c|}{ Gender } \\
\hline 1 & Male & 14 & $14.9 \%$ & 8 & $8.5 \%$ & 22 & $23.4 \%$ & 30 & $31.9 \%$ & 20 & $21.3 \%$ & 94 & $100.0 \%$ \\
\hline 2 & Female & 10 & $15.9 \%$ & 7 & $11.1 \%$ & 18 & $28.6 \%$ & 17 & $27.0 \%$ & 11 & $17.5 \%$ & 63 & $100.0 \%$ \\
\hline \multicolumn{14}{|c|}{ Designation } \\
\hline 1 & Librarian & 17 & $14.0 \%$ & 11 & $9.1 \%$ & 31 & $25.6 \%$ & 37 & $30.6 \%$ & 25 & $20.7 \%$ & 121 & $100.0 \%$ \\
\hline 2 & Asst. Librarian & 4 & $22.2 \%$ & 2 & $11.1 \%$ & 5 & $27.8 \%$ & 5 & $27.8 \%$ & 2 & $11.1 \%$ & 18 & $100.0 \%$ \\
\hline 3 & Others & 3 & $16.7 \%$ & 2 & $11.1 \%$ & 4 & $22.2 \%$ & 5 & $27.8 \%$ & 4 & $22.2 \%$ & 18 & $100.0 \%$ \\
\hline \multicolumn{14}{|c|}{ Overall } \\
\hline & Total & 24 & $15.3 \%$ & 15 & $9.6 \%$ & 40 & $25.5 \%$ & 47 & $29.9 \%$ & 31 & $19.7 \%$ & 157 & $100.0 \%$ \\
\hline
\end{tabular}

$10 \%$ to $25 \%$ of the respondents of different districts were indicated that the open access journals were very high quality. Similarly, $28 \%$ to $33.3 \%$ indicated high quality and $18.8 \%$ to $33.3 \%$ as somewhat quality. Very poor quality of open access journals ranges between $12.5 \%$ and 20\%. Among them, 25\% of respondents of Nagapattinam and Cuddalore indicated very high quality. It is followed by Villupuram (20.5\%) and Thanjavur (20\%). Similarly, $21.3 \%$ of male indicated very highly quality than female (17.5\%). 22.2\% of other library professionals indicated very high quality. It is followed by Librarian (20.7\%) and Asst. Librarians (11.1\%). 


\section{Speed of Access}

The respondent's opinion on the speed of access to open access journals were obtained in a four-point scale such as slow, somewhat fast, fast and very fast and the same has been analyzed. The responses were shown in Table 14 .

Table 14: Speed of Access of Open Access Journals

\begin{tabular}{|c|l|c|c|c|}
\hline S. No & Description & Frequency & Percent & Cumulative Percent \\
\hline 1 & Slow & 24 & 15.3 & 15.3 \\
\hline 2 & Somewhat Fast & 47 & 29.9 & 45.2 \\
\hline 3 & Fast & 31 & 19.7 & 65.0 \\
\hline 4 & Very Fast & 55 & 35.0 & 100.0 \\
\hline & Total & $\mathbf{1 5 7}$ & $\mathbf{1 0 0 . 0}$ & \\
\hline
\end{tabular}

Nearly $85 \%$ of respondents indicated somewhat fast to very fast towards the speed of access to open access journals. $35 \%$ of respondents indicated very fast in accessing the open access journals. It is followed by fast (19.7\%) and somewhat fast $(29.9 \%$. Only $15.3 \%$ indicated slow in accessing the open access journals.

The study has further been extended to the district, gender, and designation. The same has been shown in Table 15.

Table 15: Speed of Access of Open Access Journals Vs District, Gender, Designation

\begin{tabular}{|c|c|c|c|c|c|c|c|c|c|c|c|}
\hline S. No & Description & \multicolumn{2}{|c|}{ Slow } & \multicolumn{2}{|c|}{ Somewhat Fast } & \multicolumn{2}{|c|}{ Fast } & \multicolumn{2}{|c|}{ Very Fast } & \multicolumn{2}{|c|}{ Total } \\
\hline \multicolumn{12}{|c|}{ Districts } \\
\hline 1 & Ariyalur & 3 & $30.0 \%$ & 3 & $30.0 \%$ & 1 & $10.0 \%$ & 3 & $30.0 \%$ & 10 & $100.0 \%$ \\
\hline 2 & Cuddalore & 2 & $12.5 \%$ & 5 & $31.3 \%$ & 4 & $25.0 \%$ & 5 & $31.3 \%$ & 16 & $100.0 \%$ \\
\hline 3 & Nagapattinam & 1 & $6.3 \%$ & 4 & $25.0 \%$ & 4 & $25.0 \%$ & 7 & $43.8 \%$ & 16 & $100.0 \%$ \\
\hline 4 & Perambalur & 2 & $12.5 \%$ & 6 & $37.5 \%$ & 3 & $18.8 \%$ & 5 & $31.3 \%$ & 16 & $100.0 \%$ \\
\hline 5 & Thanjavur & 6 & $24.0 \%$ & 7 & $28.0 \%$ & 4 & $16.0 \%$ & 8 & $32.0 \%$ & 25 & $100.0 \%$ \\
\hline 6 & Tiruvannamalai & 4 & $16.7 \%$ & 7 & $29.2 \%$ & 4 & $16.7 \%$ & 9 & $37.5 \%$ & 24 & $100.0 \%$ \\
\hline 7 & Tiruvarur & 0 & $.0 \%$ & 1 & $16.7 \%$ & 2 & $33.3 \%$ & 3 & $50.0 \%$ & 6 & $100.0 \%$ \\
\hline 8 & Villupuram & 6 & $13.6 \%$ & 14 & $31.8 \%$ & 9 & $20.5 \%$ & 15 & $34.1 \%$ & 44 & $100.0 \%$ \\
\hline \multicolumn{12}{|c|}{ Gender } \\
\hline 1 & Male & 13 & $13.8 \%$ & 27 & $28.7 \%$ & 20 & $21.3 \%$ & 34 & $36.2 \%$ & 94 & $100.0 \%$ \\
\hline 2 & Female & 11 & $17.5 \%$ & 20 & $31.7 \%$ & 11 & $17.5 \%$ & 21 & $33.3 \%$ & 63 & $100.0 \%$ \\
\hline \multicolumn{12}{|c|}{ Designation } \\
\hline 1 & Librarian & 17 & $14.0 \%$ & 37 & $30.6 \%$ & 25 & $20.7 \%$ & 42 & $34.7 \%$ & 121 & $100.0 \%$ \\
\hline 2 & Asst. Librarian & 4 & $22.2 \%$ & 6 & $33.3 \%$ & 2 & $11.1 \%$ & 6 & $33.3 \%$ & 18 & $100.0 \%$ \\
\hline 3 & Others & 3 & $16.7 \%$ & 4 & $22.2 \%$ & 4 & $22.2 \%$ & 7 & $38.9 \%$ & 18 & $100.0 \%$ \\
\hline \multicolumn{12}{|c|}{ Overall } \\
\hline & Total & 24 & $15.3 \%$ & 47 & $29.9 \%$ & 31 & $19.7 \%$ & 55 & $35.0 \%$ & 157 & $100.0 \%$ \\
\hline
\end{tabular}

$30 \%$ to $50 \%$ of the respondents of different districts were indicated that the speed of access to open access journals was very fast. Similarly, $10 \%$ to $33.3 \%$ indicated fast and $16.7 \%$ to $37.5 \%$ as somewhat fast. The speed of access to open access journals ranges between $0 \%$ and 30\%. Among them, 50\% of respondents of Tiruvarur and $43.8 \%$ of respondents of Nagapattinam indicated very fast. It is followed by Tiruvannamalai (37.5\%), Villupuram (34.1\%), Thanjavur (32\%) Cuddalore and Perambalur (31.3\%). Similarly, 36.2\% of male indicated very fast than female (33.3\%). $38.9 \%$ of other library professionals indicated very fast. It is followed by Librarian (34.7\%) and Asst. Librarians (33.3\%). 


\section{FINDINGS}

The findings of the study were as follows

- The study was carried out with the objective to identify the Awareness; source of awareness, place of access, usability, sufficiency, quality and satisfaction over the speed of access to open access journals

- The questionnaires were distributed to the Library and Information Science professionals of 76 engineering institutions in eight districts such as Ariyalur; Cuddalore; Nagapattinam; Perambalur; Thanjavur; Tiruvannamalai; Tiruvarur and Villupuram. Nearly 210 questionnaires were distributed. Out of 210 distributed 157 responded and the response rate works out to $74.76 \%$.

- Awareness of open access journal has been ascertained based on access, cite and publish. Nearly $78.3 \%$ of the respondent have accessed the open access journals. Similarly, 60.4\% of respondents have cited open access journals in their publications and $36.3 \%$ of them published articles in open access journals.

- In the case of access, the percentage of access to open access journal ranges between 50 to $81.8 \%$. Ariyalur (80.0\%), Nagapattinam (81.3\%), Perambalur (81.3\%), Tiruvannamalai $(83.3 \%)$ and Villupuram (81.8\%) respondents access more open access journals. Female $(82.5 \%)$ access more open access journal than male (75.5\%). Asst. Librarian (88.9\%) access more open access journals than other library professionals (77.8\%) and Librarians $(76.9 \%)$.

- In relation to the citation, the percentage of citation of open access journal ranges between 50 to $75 \%$. Ariyalur (70.0\%), Perambalur (75.0\%), Tiruvannamalai (70.8\%) and Villupuram (72.7\%) respondents cite more open access journals. Tiruvarur (50\%) respondents have least cited in open access journal. Female (74.6\%) cite more open access journal than male (66.0\%). Both Asst. Librarian (72.2\%) andother library professionals (72.2\%) cite more open access journals than the Librarians (68.6\%).

- The publication of papers in open access journal ranges between 30 to $66.7 \%$. Tiruvarur has a maximum of $66.7 \%$ respondents publish a paper in Open access journals. It is followed by Cuddalore and Perambalur (37.5\%); Villupuram (36.4\%); Thanjavur (36.0\%) and Tiruvannamalai (33.3\%). Ariyalur (30\%) respondents has least published in open access journal. Female (38.1\%) publish their papers more open access journal than male (35.1\%). Asst. Librarian (38.9\%) publish more papers in open access journals than Librarians (36.4\%) and other library professionals $(33.3 \%)$.

- Out of 157 respondents, $87(55.4 \%)$ indicated that "through library" as their sources of awareness. It is followed by "Peers and Colleagues" $(38,24.2 \%)$ and "through guide" $(32,20.4 \%)$.

- $86(54.8 \%)$ respondents indicated that they access in all three locations such as home, office, and library whereas "Library" (39, 24.8\%) and "Home/Office" (32, 20.4\%).

- Nearly $80 \%$ of respondents indicated the usability of open access journals as easy. Nearly $90 \%$ of respondents indicated little to highly satisified with the sufficiency of open access journals.

- Nearly $75 \%$ of respondents indicated somewhat quality to very high quality of open access journals. Nearly $85 \%$ of respondents indicated somewhat fast to very fast towards the speed of access to open access journals. 


\section{CONCLUSIONS}

The study was carried out with the objective to identify the Awareness; source of awareness, place of access, usability, sufficiency, quality and satisfaction over the speed of access of open access journals The awareness on open access journals has been ascertained based on access, cited and published articles on open access journals. Nearly $78.3 \%$ of the respondent have accessed the open access journals. Similarly, $60.4 \%$ of respondents have cited open access journals in their publications and $36.3 \%$ of them published articles in open access journals.

In the case of the source of inspiration for open access journal were 87 (55.4\%) indicated that "through library" as their sources of awareness. It is followed by "Peers and Colleagues" $(38,24.2 \%)$ and "through guide" $(32,20.4 \%)$. This study indicates that they access in all three locations such as home, office, and library besides "Library" and "Home/Office". The usability of open access journals as easy and highly satisfies with the sufficiency of open access journals. The open access journals were of high quality. Similarly speed of accessing open access journals somewhat fast to very fast. Their exist awareness on open access journals has been ascertained based on access, cited and published articles on open access journals irrespective of the district, gender, and designation. Their exist uniform opinion on usability, sufficiency, quality and satisfaction over the speed of access of open access journals irrespective of the district, gender, and designation of the respondents. Thus the success of the use of open access journals were primarily depended on the prevailing mindset of the user.

\section{REFERENCES}

1. Aliyu, A. and Mohammed, Z. (2014), "Deployment of Ahmadu Bello University Zaria, Nigeria Institutional Digital Repository”, Information Manager, The 13(1-2), 30-34.

2. Bartle and Walton, (1996) Bartle \& Walton, A. (1996). Awareness of electronic journals. fromhttp:san.undo.org/gpgn/topics.php Accessed on 17th February 2016.

3. Dulle, W. F., Minish-Majanja, K. M., and Cloete, M. L. (2010). Factors influencing the adoption of OAJs scholarly communication in Tanzania public universities. World library and information congress: 76th IFLA general conference and assembly 10-15 August 2010, Gothenburg, Sweden Available http://www.ifla.org/en/ifla76 accessed on 17th November 2018.

4. Ezema, I. (2011). Building open access institutional repositories for global visibility of Nigerian scholarly publication. Library Review, 60(6), $473-485$.

5. Jain, P. (2012), "Promoting Open Access to Research in Academic Libraries", Library Philosophy and Practice (e-journal), Paper 737, Retrieved March 09, 2017, http://digitalcommons.unl.edu/libphilprac/737.

6. Jose, J. (2014), "Use and Awareness of Open Access E-resources among Academicians in Kerala: An Overview", International Journal of Engineering Sciences and Research Technology 3(7), 412-416.

7. Joshi, A.N., Vatnal, R. M. and Manjunath, G. A. (2012), “Open Access Initiatives: A Boom to Academic Libraries", Library Philosophy and Practice (e-journal), Paper 792, Retrieved December 09, 2016, www.webpages.uidaho.edu/ mbolin/joshivatnal2.htm

8. Kayvan Kousha, (2009) "Characteristics of open access scholarly publishing: A multidisciplinary study", Aslib Proceedings, Vol. 61 Issue: 4, pp.394-406, https://doi.org/10.1108/00012530910973794

9. Kenneway, M. (2011), “Author Attitudes towards Open Access Publishing”, TBI Communications, INTECH Open Access Publisher, 1-18. 
10. Korobili, S., Tilkidu, I., \& Delistavrou, A. (2005). Factors that influence the use of library resources by faculty members. Library Review, 55(2), 91-105

11. Nwagwu, E. W. (2013). Open Access Initiatives in African-Structure Incentives and Disincentives. The Journals of Academic Librarianship, 39(1), 3-10.

12. Okoye, \& Ejikeme, (2010). Open access, institutional repositories and scholarly publishing: The role of librarians in South East Nigeria. Journal of Nigeria Library Association: 48th National Conferences.

13. Pandita, R. (2013). Publication Distribution of Open Access Journals at Continental Level; an Analysis of Directory of Open Access Journals (DOAJ). International Journal of Digital Library Services. 3(3), 65-83.

14. Suber, P. (2006). An introduction to open access. Available: http//www.blurtit.com/q72848.html.

15. Suber, P. (2008), "Gratis and Libre Open Access", Distal Access to Scholarship at Havard, Retrieved December 14, 2016, http://dash. harvard.edu/handle/1/4322580.

16. Suber, P. (2012), “Open Access', Cambridge, USA, 255.

17. Suber, P. (2013), “Open Access Overview', Retrieved January 06, 2017, earlham.edu/n peters/overview.htm.

18. Paliwal, S. (2016). Comparative Bibliometric Study of ALIS and DESIDOC Journal of Library and Information Technology: 2010-2014.

19. Twaakyondo, M. H. (2013). Challenges to Open Access in Teaching at University of Dar Es Salaam (UDSM). International Journal of Engineering Research and Applications, 3(4), 694-696.

20. Ware, M. and Mobe, M. (2015). STM Report: An Overview of scientific and scholarly journals publishing, (4th Ed.) Available www.markwareconsulting.comAccessed on 17th February 2016. 